\title{
International Policies Toward Parental Leave and Child Care
}

\section{Jane Waldfogel}

\section{SUMMARY}

The pleasures and pressures of parenting a newborn are universal, but the supports surrounding parents vary widely from country to country. In many nations, decades of attention to benefits and services for new parents offer lessons worthy of attention in this country. This article describes policies regarding parental leave, child care, and early childhood benefits here and in 10 industrial nations in North America and Europe. The sharpest contrast separates the United States from the other countries, although differences among the others also are instructive:

D The right to parental leave is new to American workers; it covers one-half of the privatesector workforce and is relatively short and unpaid. By contrast, other nations offer universal, paid leaves of 10 months or more.

- Child care assistance in Europe is usually provided through publicly funded programs, whereas the United States relies more on subsidies and tax credits to reimburse parents for part of their child care expenses.
D Nations vary in the emphasis they place on parental leave versus child care supports for families with children under age three. Each approach creates incentives that influence parents' decisions about employment and child care.

- Several European nations, seeking flexible solutions for parents, are testing "early childhood benefits" that can be used to supplement income or pay for private child care.

Based on this review, the author urges that the United States adopt universal, paid parental leave of at least 10 months; help parents cover more child care costs; and improve the quality of child care. She finds policy packages that support different parental choices promising, because the right mix of leave and care will vary from family to family, and child to child.

Jane Waldfogel, Ph.D., is associate professor of social work and public affairs at Columbia University. 
$\mathrm{T}$ he birth of a new child, and the first few weeks, months, and years of the child's life, are a time when the tensions between the obligations of work and child rearing are particularly acute. Infants and toddlers need constant adult attention, whether it comes from a parent or from another caregiver, and that constant attention comes at a price, whether in foregone earnings for the parent or in the cost of alternative care. Moreover, the cost of caring for a child comes at exactly the time when families are incurring other costs-buying all the gear that babies need, plus food, diapers, and so on. Having an extra mouth to feed means that families find themselves having to stretch their incomes further when a new baby arrives, and this stretch plunges some families into poverty, or perilously close to it. Recent estimates suggest that one quarter of all poverty spells in the United States begin with the birth of a new child. ${ }^{1}$ The pressures of caring for a new child are not all financial either. With the arrival of a new child, the mother must recover from childbirth, adults in the household must adapt to disrupted sleeping patterns, and everyone experiences changes in their daily routines. The responsibilities associated with parenting an infant and toddler are exhilarating, but also exhausting.

Although the pressures of caring for a new child are universal, there is a good deal of variation across countries in the types of policies that governments use to support new parents (and all parents in general). Thus, there is value in looking beyond the borders of this country to observe what other countries do. Although the policies of other countries must be viewed in the context of how surrounding conditions support or challenge particular policy approaches, there is nevertheless much that the United States can learn from other countries about the range of policy options that might be used to support families as they arrange the day-to-day care of their young children.

This article provides an overview of the approaches that 10 peer countries take on the three major types of policies for infant and toddler care-parental leave, child care, and early childhood benefits - and it contrasts those approaches to the policy choices the United States has made to date. The countries included are Austria, Canada, Denmark, Finland, France, Germany, Italy, Norway, Sweden, and the United Kingdom-all members of the Organization of Economic and Community Development (OECD), that includes the 29 most advanced industrialized economies. ${ }^{2}$ These OECD countries were chosen for comparison with the United States because data were available for them on the policy elements being considered in this article (that is, parental leave and child care provisions), and because they represent the three major types of social welfare states (Anglo-American, Nordic, and Continental European). In most of the countries described, it is important to note that the policies considered in this article occur within the context of an array of health and social services programs that provide medical care for infants and toddlers and also support parents in their parenting role. Such policies include health insurance, well-baby and immunization services, home health visiting programs, and so on. These policies have been documented in detail by Sheila Kamerman and Alfred Kahn, ${ }^{3,4}$ who note the extent to which the United States lags behind other countries in their provision. This article considers the relative merits of the various types of policies supporting infant and toddler care, and it concludes by drawing lessons for the future direction of U.S. policy. 


\section{If a country offers little parental leave but more generous child care subsidies, parents are likely to return to work earlier and place children in child care.}

\section{Three Policy Options}

Governments have typically used two major types of policies to help parents arrange day-to-day care for young children, and a few countries have begun experimenting with a third type. These three policies are parental leave policies, child care policies, and early childhood benefits. Parental leave policies - whether in the form of maternity leave (for mothers), paternity leave (for fathers), or parental leave (for mothers or fathers - - help parents who were employed before the birth to remain at home for a period of time so that they can provide care for the child themselves. Usually, although not always, parental leave policies provide the right not only to a job-protected leave but also to some income replacement during the leave. Child care policies, in contrast, help parents pay for nonparental care for the child by subsidizing the care that parents select, or by providing care directly through public programs. Child care programs serve children of both working and nonworking parents.

The third, newer policy approach to support parents in arranging the day-to-day care of their child is the use of early childhood benefits. These benefits are essentially cash grants that can be used to cover the costs of caring for an infant or toddler, whether those costs involve foregone earnings (because a parent is staying home from work), or child care payments (because the family is purchasing nonparental care for the child), or some combination of the two. Although many countries outside the United States have historically had special maternity grants for women with newborns, early childhood benefits that extend into the first few years of life and that are provided, whether or not the parents are in paid work, are a relatively new phenomenon. Thus, early childhood benefits now constitute a third way that governments are helping parents arrange care for infants and toddlers.

A country's choice of a policy or set of policies can influence the decisions that parents make about care arrangements for their children. If a country offers generous parental leave but little child care, one would expect parents to be more likely to stay at home with their children than to use nonparental child care. Alternatively, if a country offers little parental leave but more generous child care subsidies, parents are likely to return to work earlier and place children in child care. In the absence of strong reasons to believe that government should induce parents toward one form of care arrangement rather than another, it is likely that the best approach is one that gives parents choices. One way to do so is to offer both parental leave and child care subsidies, so that parents can choose the mix of parental and nonparental care that is right for their family. Another way is to offer flexible supports, such as early childhood benefits, that parents can use to subsidize the cost of leave or the cost of child care.

\section{Parental Leave Policies}

Until 1993, the United States was one of the few industrialized countries without maternity leave legislation. Even since the passage of the Family and Medical Leave Act (FMLA) in that year, the United States still stands out as having particularly minimal legislation. This section reviews the provisions of the FMLA, compares it to the legislation of other countries, and summarizes evidence about the impact of such legislation on parents and children.

\section{Family Leave in the United States}

The FMLA provides the right to a short (12-week), jobprotected parental leave for workers who meet qualifying conditions (that is, those who work in firms of at least 50 employees and have worked at least 1,250 hours in the prior year). Because of these qualifying conditions, fewer than one-half of the nation's private-sector workers are eligible for leave guaranteed by the FMLA., ${ }^{5,6}$ A further limitation of the FMLA as a family leave policy is that it does not include any income replacement or pay during the leave; as a result, some workers who are eligible for leave do not take it. ${ }^{7}$ (See the article by Asher and Lenhoff in this journal issue.)

In spite of these limitations, the FMLA has had quite a dramatic impact on parental leave coverage in the United 


\section{A long period of leave may make it harder for a woman to maintain her attachment to her employer and advance in her career.}

States, especially for male workers as few men previously had the right to a paternity leave. ${ }^{5}$ However, the impact of the law on parental leave usage has been less pronounced. Studies thus far have found generally small effects of the U.S. law on leave usage by new mothers, ${ }^{8-11}$ and they have found no discernible effects on leave usage by new fathers. ${ }^{11}$ The fact that the law extended coverage, but had so little impact on usage, suggests that there are limits to the extent to which families are willing and able to use the unpaid leave offered under the FMLA. Given the financial constraints that families with new children often face, taking leave without pay may simply not be an option for many of them.

\section{Leave Policies in Other Nations}

The parental leave policies in the countries described here ${ }^{12-14}$ differ from those in the United States in three major respects. First, the policies of other countries tend to provide a longer period of leave-an average of 10 months of childbirth-related leave in the developed nations that make up the OECD. ${ }^{12}$ Second, other countries' policies typically provide some form of wage replacement (for parents who were employed prior to the birth) or income supplementation (for parents who were not employed prior to the birth). ${ }^{15}$ Third, the policies of the other countries tend to be universal, covering all new mothers (maternity leave), all new fathers (paternity leave), or all new parents (parental leave). These cross-country differences reflect the historical origins of these policies. In countries other than the United States, maternity leave policies were introduced more than a century ago as a way of protecting the health of women and children. ${ }^{12}$ Seen from a health perspective, it is not surprising that these policies provide for sufficient time off from work for a woman to recover from childbirth and to be home breast-feeding, that they provide income support as well as time off, and that they are universal in coverage.

When one compares the United States to peer nations, the differences in parental leave policies are striking, as can be seen in Table 1 . In contrast to the United States, which offers fewer than three months of leave following childbirth and no wage replacement, Canada offers more than six months of childbirth-related leave (17 weeks maternity leave, plus 10 weeks of parental leave), and all but two weeks of the leave are paid at the rate of $55 \%$ of prior earnings. In the advanced European countries in Table 1, the periods of leave-nearly all paidare even longer. The Nordic countries have very generous leave policies, ranging from 18 months in Denmark and Sweden, to three years in Norway and Finland. The continental European countries are also generous in comparison to the United States, guaranteeing leaves that range from 11 months in Italy to 3.3 years in Germany. Most similar to the United States, the United Kingdom lacked universal coverage until recently, but it now provides 18 weeks of maternity leave to all new mothers, paid as a percentage of prior earnings or as a flat rate depending on the woman's prior employment status. The United Kingdom recently added an unpaid parental leave of up to 13 weeks, which can be taken by a mother or father any time during the first five years of a child's life.

Take-up of these parental leave policies is very high, particularly on the part of women, and so too is reported satisfaction with them. ${ }^{12,14}$ As would be expected, leave policies significantly influence women's employment and leave-taking behavior. When leave periods are extended or when benefits become more generous, women take longer leaves; similarly, when leave benefits are curtailed, women take shorter leaves. ${ }^{16}$ Men, in contrast, have been much less responsive to changes in leave policies-even in Sweden, the country that has made the greatest effort to promote paternity leave. ${ }^{17}$ Thus, a number of countries are now experimenting with ways to induce fathers to take more leave. One provision that has been tried in countries, such as Norway and Sweden, is the introduction of "use it or lose it" policies that provide additional leave time for the family that can be used only by the father. ${ }^{13}$

\section{Costs and Benefits of Long Leaves}

There is no consensus internationally as to how long parental leaves should last. Lengthy leaves - extending beyond the first year of life into the second and third year, and taken predominantly by women-have both costs and benefits. ${ }^{18}$ 


\section{Table 1}

\section{Childbirth-Related Leave Policies in the United States and 10 Peer Nations}

\begin{tabular}{|c|c|c|c|}
\hline Country & Type of Leave Provided & $\begin{array}{l}\text { Total Duration } \\
\text { (in months) }\end{array}$ & Payment Rate \\
\hline United States & 12 weeks of family leave & 2.8 & Unpaid \\
\hline Canada & $\begin{array}{l}17 \text { weeks maternity leave } \\
10 \text { weeks parental leave }\end{array}$ & 6.2 & $\begin{array}{l}15 \text { weeks at } 55 \% \text { of prior earnings } \\
55 \% \text { of prior earnings }\end{array}$ \\
\hline Denmark & $\begin{array}{l}28 \text { weeks maternity leave } \\
1 \text { year parental leave }\end{array}$ & 18.5 & $\begin{array}{l}60 \% \text { of prior earnings } \\
90 \% \text { of unemployment benefit rate }\end{array}$ \\
\hline Finland & $\begin{array}{l}18 \text { weeks maternity leave } \\
26 \text { weeks parental leave } \\
\text { Childrearing leave until child is } 3\end{array}$ & 36.0 & $\begin{array}{l}70 \% \text { of prior earnings } \\
70 \% \text { of prior earnings } \\
\text { Flat rate }\end{array}$ \\
\hline Norway & $\begin{array}{l}52 \text { weeks parental leave } \\
2 \text { years childrearing leave }\end{array}$ & 36.0 & $\begin{array}{l}80 \% \text { of prior earnings } \\
\text { Flat rate }\end{array}$ \\
\hline Sweden & 18 months parental leave & 18.0 & $\begin{array}{l}12 \text { months at } 80 \% \text { of prior earnings, } \\
3 \text { months flat rate, } 3 \text { months unpaid }\end{array}$ \\
\hline Austria & $\begin{array}{l}16 \text { weeks maternity leave } \\
2 \text { years parental leave }\end{array}$ & 27.7 & $\begin{array}{l}100 \% \text { of prior earnings } \\
18 \text { months of unemployment } \\
\text { benefit rate, } 6 \text { months unpaid }\end{array}$ \\
\hline France & $\begin{array}{l}16 \text { weeks maternity leave } \\
\text { Parental leave until child is } 3\end{array}$ & 36.0 & $\begin{array}{l}100 \% \text { of prior earnings } \\
\text { Unpaid for one child; paid at flat rate } \\
\text { (income-tested) for two or more }\end{array}$ \\
\hline Germany & $\begin{array}{l}14 \text { weeks maternity leave } \\
3 \text { years parental leave }\end{array}$ & 39.2 & $\begin{array}{l}100 \% \text { of prior earnings } \\
\text { Flat rate (income-tested) for } 2 \text { years, } \\
\text { unpaid for third year }\end{array}$ \\
\hline Italy & $\begin{array}{l}5 \text { months maternity leave } \\
6 \text { months parental leave }\end{array}$ & 11.0 & $\begin{array}{l}80 \% \text { of prior earnings } \\
30 \% \text { of prior earnings }\end{array}$ \\
\hline United Kingdom & 13 weeks parental leave & 7.2 & $\begin{array}{l}90 \% \text { for } 6 \text { weeks and flat rate for } 12 \\
\text { weeks, if sufficient work history; } \\
\text { otherwise, flat rate } \\
\text { Unpaid }\end{array}$ \\
\hline
\end{tabular}

Source:Kamerman, S.B. From maternity to parental leave policies: Women's health,employment,and child and family well-being. The Journal of the American Women's Medical Association (Spring 2000) 55: Table 1; Kamerman, S.B. Parental leave policies:An essential ingredient in early childhood education and care policies. Social Policy Report (2000) 14: Table 1.0.

On the down side, a long period of leave may make it harder for a woman to maintain her attachment to her employer and advance in her career. There may be negative effects on wages for women overall ${ }^{19}$ because long leave periods may lead employers to view women as temporary employees and refrain from hiring, training, and promoting them. The fact that it is mainly women who take leaves and bear these consequences raises concerns about the extent to which lengthy parental leaves may impede progress toward gender equity in the labor market. A related concern is that lengthy leaves also reinforce the traditional gender division of labor in the home. There are also potential connections between more generous leave policies and higher rates of fertility, although there may also be offsetting effects that reduce fertility (if, for instance, longer leaves were associated with reduced infant mortality, which in turn would reduce subsequent fertility)..$^{20}$ Moreover, exclu- 


\section{Extending the total duration of childbirth-related leave to 10 months (the OECD average), and providing universal and paid coverage (as other countries do), would be prudent next steps.}

sive parental care that extends into the second and third year of life may not be optimal for children's development. (See the article by Phillips and Adams in this journal issue.)

However, on the up side, longer leaves that extend beyond the first few months of life are associated with improved health outcomes for women and children. ${ }^{21,22}$ These beneficial health effects may come about in part through breast-feeding. Breast-feeding is associated with better health outcomes for children, ${ }^{23}$ and women who take leave are more likely to initiate breast-feeding and to continue the practice for a longer period of time. ${ }^{24}$ Leaves that extend beyond the first six months of life are also associated with higher rates of employment for women of child-bearing age, ${ }^{19}$ presumably because such policies provide an incentive for women to be employed before having children.

There may also be links between longer leaves and improved child development outcomes. A number of studies in the United States have found adverse effects on cognitive development or behavioral problems for children whose mothers work in the first year, particularly for those whose mothers work early and/or long hours in the first year of the child's life. ${ }^{25}$ These effects tend to be small, are not found for all children or in all studies, and may not persist beyond the preschool years. This literature, nevertheless, suggests that some children might do better along some dimensions if their mothers had the chance to stay home for a longer period of time in the first year of life.

Thus, in thinking about lessons to be drawn from other countries, the United States should strive to get the balance right. Expanding parental leave provisions-so that leaves extend beyond the 12 weeks currently available under U.S. legislation, are universally available, and are paid-would clearly have many positive benefits for women and children. If the leaves extended into the second and third year of life, however, the risk might arise that women would become too detached from the labor market, with adverse consequences for their own careers and for those of other women. Also children who were in exclusive parental care during the first three years of life might become too socially isolated. Fortunately, however, there is plenty of room in the United States for significant parental leave expansions without running these risks. Extending the total duration of childbirthrelated leave to 10 months (the OECD average), and providing universal and paid coverage (as other countries do), would be prudent next steps.

\section{Child Care Policies}

The second major way governments help families care for infants and toddlers is through child care policies. This section offers a brief comparison between child care policies in the United States and other nations, and it reviews evidence regarding the impact of child care policies on parents' decisions and children's experiences. (For a fuller discussion of child care issues, see the article by Phillips and Adams in this journal issue.)

\section{Public Support of Child Care}

Governments may provide child care directly, or they may subsidize or reimburse some of the costs of care that parents purchase from the private market. One useful way to summarize the level of support that a country provides is to calculate the share of children who are enrolled in care that is either publicly provided or that is at least partly subsidized or reimbursed by government. As shown in Table 2 , in general, the United States provides a lower level of child care support than the 10 peer nations listed. ${ }^{26,27}$ Only $5 \%$ of U.S. children under age three, and only $54 \%$ of children ages three to six, are in publicly supported child care. This latter figure for the United States may seem high given that only about $15 \%$ of eligible low-income families receive subsidized care, but a substantial share of families receive some public support through tax credits or through the enrollment of their children in publicly provided preschools or kindergarten programs.

Although the child care figures for Canada are quite comparable, the figures for the other nations in Table 2 are considerably higher. In the Nordic countries, the share of zero- to three-year-olds in publicly supported care ranges from a low of $20 \%$ in Norway to a high of $48 \%$ in Den- 


\section{Table 2}

\section{Publicly Supported Child Care in the United States and 10 Peer Nations}

\begin{tabular}{lcccc} 
Country & \multicolumn{2}{c}{$\begin{array}{c}\text { Percentage of Children in Publicly Supported Care } \\
\text { Age 0-2 }\end{array}$} & Age 3-6 & Share of Child Care Costs Covered by Government \\
Age 0-2 3-6
\end{tabular}

Source:Data on percentage of children in subsidized care from Kamerman, S.B. Early childhood education and care:An overview of developments in the OECD countries. International Journal of Educational Research (2000) 33:7-29, Table 1; and Meyers,M.K.,and Gornick, J. Cross-national variation in ECEC service organization and financing. In Early childhood education and care:International perspectives, S.B. Kamerman,ed. New York:Institute for Child and Family Policy, Columbia University, 2001,pp.141-76, Table 4. Data on share of child care costs covered by government calculated,using data from Meyers and Gornick,2001, Table 5.

mark, while the share of three- to six-year-olds in publicly supported care ranges from $53 \%$ in Finland to $82 \%$ in Denmark. The continental European countries have lower rates of enrollment for zero- to three-year-oldsranging from a low of $2 \%$ in Germany to a high of $23 \%$ in France, but enrollment for three- to six-year-olds are universally high-ranging from $78 \%$ in Germany to $99 \%$ in France. Even the United Kingdom, which has historically lagged behind other European countries in child care provision, has a higher share of children ages three to six in publicly supported care than does the United States (although very few British children under age three are in publicly supported care). Child care enrollments in the United Kingdom will soon rise for three- to six-year-olds as a result of a national child care strategy, which pledges to make a publicly funded preschool space available to all three- and four-year-olds.

Countries also vary in the extent to which the costs of child care are borne by government or by parents. ${ }^{26,27}$ Although data are not available for all countries, the pattern of results in Table 2 indicates that here, too, the United States lags behind other countries. One estimate suggests that the U.S. government covers $25 \%$ to $30 \%$ of the cost of child care for children under age three and children ages three to six. (This support takes several forms in the United States: tax credits to reimburse parents for child care fees, subsidies given to parents, and care that is purchased for free or at a reduced cost.) In the other countries for which data are available (Denmark, Finland, France, Norway, and Sweden), government funds the majority of the costs of care, covering between $68 \%$ and $100 \%$ of the costs depending on the country and the age of the child.

\section{Expectations of Government}

What accounts for the widely varying proportions of children in publicly funded care and the widely varying share of the costs of care covered by government? In part, these differences are linked to the differences in parental leave policies, as shown in Table 1. Some countries, such as Germany, offer lengthy parental leave in place of public support for child care. However, these differences in child care provision also reflect differing views of the government's role in providing care and education for children in the early years.

In the United States, the use of child care for infants and toddlers is seen as essentially a private decision, with the 
government bearing little or no obligation to assist with the costs, unless child care is necessary to help a lowincome parent remain employed or unless an early intervention program is necessary to prepare a disabled or disadvantaged child for school. (See the articles by Sylvester and by Knitzer in this journal issue.) Although the United States does provide tax credits that help with child care expenses for working families of all income levels, and although an increasing number of states are providing no-cost preschool services prior to kindergarten, the investment that the United States makes in early childhood care and education pales by comparison to the investments being made by other countries. One recent study found that the United States spends $\$ 600$ per year per preschool-age child on early childhood care and education, whereas France spends five times that amount (nearly $\$ 3,000$ dollars), and Sweden spends seven and one-half times that amount (more than $\$ 4,500$ ). ${ }^{27}$

In the Nordic countries and many other European countries, child care is seen as a public responsibility and a public good, like elementary and secondary education. These countries have long had universal provision of preschool care for children age three and older, and the Nordic countries have recently moved to guarantee a child care space for all children age one or older whose parents seek care. ${ }^{26}$ Although child care systems vary across countries (see Box 1 for an overview of four peer countries that are widely recognized as leaders in child care provision), a common feature is that child care is relied upon to prepare children for school and adult life, and it is also seen as a

\section{Box 1}

\section{Child Care Systems in Four Leading Countries}

\section{Denmark}

Denmark has a mixed public/private system of care, with about two-thirds of the care publicly provided and about one-third provided by private organizations. The costs of both public and private care are heavily subsidized by the government, and parents pay fees that depend on their incomes (but in no instance exceed $20 \%$ to $30 \%$ of the costs of care). Enrollment rates have traditionally been very high for older preschoolers, and children are now guaranteed a child care space, if the family wants one, starting at age one. Programs serving children up to age six are overseen by the ministry of social services.

\section{Sweden}

Sweden has a public child care system that relies mainly on child care centers but also uses some family child care homes. The majority of the costs of care are subsidized, and parents pay fees that cover not more than $13 \%$ of costs (depending on their income). Enrollment rates have traditionally been very high for older preschoolers, and children are now guaranteed a child care space starting at age one, if the parents are working or in school. Sweden's child care system originally operated under the auspices of its social welfare system but has recently been transferred to the education ministry.

\section{France}

France has a dual child care system. Care for younger children is provided under the auspices of the social welfare system, in child care centers, family child care homes, or with other caregivers. These services are publicly funded, and parents pay a small share of the costs (but not more than $30 \%$ ) depending on their income. Starting at age two, children can attend preschools (écoles maternelles),operated under the auspices of the education system; these preschools are universally available and provided free of charge, like public schools. Enrollment rates in the écoles maternelles for children age three and up are near $100 \%$, and France has made a commitment to boost enrollment rates for two-year-olds from their current level of about $40 \%$ to $100 \%$.

\section{Italy}

Italy, like France, has a dual child care system. Younger children are served in child care settings provided through the social welfare system. These services are mainly used by working parents, who pay a small share of the costs (but not more than 20\%) depending on their income. Older children are served in free universal preschools (scuola materna) operated under the auspices of the education system. Most of these preschools are public, but about one-third are private or church affiliated.

Source:Kamerman, S.B. Early childhood education and care:An overview of developments in the 0ECD countries. International Journal of Educational Research (2000) 33:7-29; Meyers,M.K., and Gornick, J. Cross-national variation in ECEC service organization and financing. In Early childhood education and care:International perspectives, S.B. Kamerman,ed. New York:Institute for Child and Family Policy, Columbia University, 2001,pp. 141-76. 


\section{What is best for one child or one family may not be optimal for another child or family. The right mix of parental leave and child care in the first three years of life will vary from child to child.}

valuable end in itself, providing important social experiences for children.

The more limited role played by the government in child care provision in the United States is also reflected in the way in which the United States funds child care. The United States relies mainly on giving parents subsidies (or tax credits) to support their purchase of private child care, rather than offering places in publicly provided care. ${ }^{28}$ Thus, the government has little direct control over the type of child care offered or the quality of that care. Although state and local governments attempt to influence quality through licensing efforts, the resulting private child care system is of widely varying quality, and much of the care offered has been found to be of only moderate or poor quality. ${ }^{29}$ In other countries, in contrast, a larger share of child care is provided directly by government, either through the social welfare system or through the education system, and quality standards are more uniform and more rigorously upheld.

Thus, if the United States were to catch up with other countries in the area of child care provision, it would need to take several steps: provide more support for the costs of care for young children, provide universal and publicly funded programs for children ages three to six, and undertake efforts to improve the quality of care delivered in child care settings serving children from birth to school entry.

\section{Balancing Leave and Child Care Benefits}

Before leaving the topic of child care, it is important to note that another important point of difference between the United States and other countries is in the balance between parental leave and child care policies. It is apparent from Tables 1 and 2 that the United States, although less generous in child care policy than other peer countries, is nevertheless more generous in child care policy than it is in parental leave policy. Other countries (Germany, for example) go in the opposite direction, providing more support for parental leave than for child care. Still others (France and several countries in the Nordic group, for example) have adopted a more balanced approach, offering generous parental leave and generous child care benefits-and essentially allowing parents to choose the support that best meets their needs.

To the extent that policies influence parental behaviors and/or child outcomes, these differences in the balance between parental leave and child care matter. As discussed earlier, there is a good deal of evidence that parental leave policies influence the behavior of parents (particularly mothers). Child care policies matter too. Policies that lower the cost of care or increase the availability of care increase the likelihood that women will work in the labor market and will use nonparental care. ${ }^{30}$ These decisions also affect children in varying ways that are not constant across all children (for a fuller discussion, see the article by Phillips and Adams in this journal issue). What is best for one child or one family may not be optimal for another child or family. The right mix of parental leave and child care in the first three years of life will vary from child to child. Thus, there is value in policy packages, such as those provided by France and some Nordic countries, which let parents make their own choices between parental care and nonparental care in the first three years of life.

\section{Early Childhood Benefits}

Another way to offer parents choices is through the provision of early childhood benefits-cash grants to families with children under age three that can be used to offset the costs of foregone parental earnings or the costs of nonparental care. This section describes the early childhood benefits that some countries are offering and reviews the pros and cons of these benefits. Because this policy gives parents a choice between providing care themselves and purchasing care, or some combination of the two, it does not-in and of itself-distort parent behavior. Nevertheless, shifting from a parental leave or child care approach to this more choice-oriented approach could change the incentives facing parents, and it is important to consider these potential effects.

\section{How Early Childhood Benefits Work}

The concept of giving parents an extra cash grant dur- 
ing the first few years of life is not a new one. Experts ${ }^{8}$ credit Hungary with being the first country to introduce this type of child-rearing allowance in 1967 and note that this type of policy then spread throughout Eastern Europe and, later, Western Europe. The primary goal of these early cash grant policies was to allow women to stay home for an extended period of time with young children. Another goal was to reduce the female labor supply during periods of high unemployment to reserve available jobs for men. Many countries today offer some form of cash benefit for parents on leave, as indicated in the earlier discussion of parental leave policies. However, these policies typically are restricted to parents who do not work in the labor market, or who limit their hours to part time.

Early childhood benefits, in contrast, are provided to all parents with children under age three regardless of whether or not they work in the labor market. These benefits are explicitly designed to allow families to choose parental care or child care, or some combination of the two. Early childhood benefits differ from welfare in that they are provided to all parents, regardless of income or employment status. They differ from child benefits or child allowances (a common form of benefit outside the United States) in that they are provided only to families with children under age three. And, as noted above, they differ from parental leave benefits in that they are not limited to parents on leave from work. Very few countries currently offer this type of benefit.

\section{Implementation in Other Nations}

Finland, in 1985, was the first to introduce an early childhood benefit. The grant is available to all families with a child under age three who are not using publicly funded child care. Given that Finland guarantees a publicly funded child care place for all children age one or older whose parents desire one, the early childhood benefit gives parents a choice between parental care, private child care, or public child care. A parent in Finland can choose to remain home and receive the child-rearing benefit, to work and use private child care and receive the child-rearing benefit, or to work and use public child care (instead of receiving the child-rearing benefit). Data on take-up of this cash benefit are limited, but it appears to be used by many women with infants, though the most popular option for toddlers remains publicly provided child care. ${ }^{31,32}$ It is unclear how much impact the policy has had on women's labor force participation. Studies have found that the introduction of the cash benefit was associated with lower labor force participation rates for women with young children, but high unemployment rates in the early 1990 s were also a factor influencing women's employment. ${ }^{32,33}$

The other Nordic country with an early childhood benefit is Norway. (Sweden enacted a child-rearing grant in 1994 but repealed it the following year before it came into effect owing to concerns about the law's impact on the country's commitment to publicly funded child care. ${ }^{34}$ ) After considerable debate, Norway enacted a 


\section{Providing flexible funds to parents does not improve the quality of child care on offer; parents might use the funds to purchase more child care or better child care, or they might use the funds to purchase other items.}

child-rearing grant in 1998 that provides a cash benefit to parents of children age 12 months to 36 months. The benefit is roughly equal to the amount the government would pay for a publicly funded child care space and, like Finland's, it is provided on the condition that the child not attend publicly funded child care. Norway's policy has been controversial. ${ }^{34}$ Although it was intended to give families more time to care for children and more choices in care arrangements, and to equalize the benefits offered to families who do and do not use publicly funded care for children under age three, the law has also had a number of other consequences. Given the shortage of publicly funded child care spaces and the fact that the new grant can only be used to purchase private care, the law has led to an expansion in the use of private care. The pressure to expand publicly funded care has eased, and the growth of publicly funded spaces has slowed. In the long run, then, the new policy may shift children from public sector child care into privatesector child care, which may or may not be desirable. Because the policy also subsidizes parental care, it may also induce women to stay out of the labor force longer. Again, this may or may not be desirable.

In addition to these Nordic countries, Austria is currently considering a universal early childhood benefit that parents could use to subsidize either parental care or purchased child care. ${ }^{12}$ This option is also receiving some attention in the United Kingdom. ${ }^{35}$ The provision of public child care in both these countries is fairly low, however, and private care is expensive relative to the proposed amount of the benefit. Therefore, the extent to which these child-rearing allowances will really give Austrian and British parents choices between staying at home or using child care is questionable.

\section{Relevance in the U.S. Context}

What impact would an early childhood benefit have in the United States? As suggested earlier, the United States has historically had more generous child care than parental leave provisions. Therefore, in the U.S. context, giving parents a grant that they could use to either stay home or purchase child care could give parents, mainly women, an incentive to spend more time at home. This may or may not be better for children (many experts feel that the typical period of maternity leave taken in the United States is too short, but the evidence that children of mothers who return to work early are harmed by this is mixed). Such a shift may or may not be better for parents (because lengthy periods out of the labor market can have long-term negative effects on the employment and earnings of parents-mainly mothers). ${ }^{18,19}$

It would also matter whether an early childhood benefit was instituted in place of, or in addition to, existing child care subsidies and tax credits. One expert ${ }^{36}$ argues that if a cash benefit, like an early childhood benefit, replaced existing child care supports, it would be a boon to stay-at-home mothers without helping working mothers. It could even make stay-at-home mothers better off at the expense of working mothers, if funding were held constant. Providing flexible funds to parents also does not improve the quality of child care on offer; parents might use the funds to purchase more child care or better child care, or they might use the funds to purchase other items for their children or themselves. ${ }^{37}$ Moreover, as discussed earlier, providing incentives for mothers to stay at home longer raises concerns about gender equity. However, providing support for stay-athome mothers might be the price that must be paid in the U.S. context to secure more public support to fund higher-quality child care for working mothers. ${ }^{36}$ If an early childhood benefit were implemented alongside strengthened support for child care subsidies or tax credits, as well as incentives for parents to use higher quality child care, it might expand the set of choices facing parents by making parental care, as well as child care, more affordable.

The impact of early childhood benefits would also depend on the level at which such benefits were funded. If benefits were not sufficient to allow a woman to forego work and stay home, then their impact on employment and care arrangements for children would 
be minimal. Benefit levels in the two countries with such programs to date (Finland and Norway) have allowed women to stay home for a period of time. The fact that most women return to work and use publicly funded child care in the second year, however, indicates that either the benefit is not sufficient to allow them to stay home longer, or that they prefer to work and use child care at that stage.

Clearly, there are many questions to be answered with regard to the merits and feasibility of early childhood benefits as a policy to support families with young children. But, given the capacity of early childhood benefits to support parental choice around very personal decisions involving the care of infants and toddlers, it is also clear that this policy option deserves serious consideration.

\section{Conclusions}

The evidence reviewed here shows that, indeed, the United States differs sharply from other countries in its parental leave and child care provisions. What are the implications of these differences for future U.S. policy? Should the nation move to extend parental leave rights, to expand support for infant and toddler child care, to implement early childhood benefits; or should it pursue some combination of these?

The answers to these questions are not clear-cut. Too little is yet known about what care arrangements are best for children (keeping in mind that no one set of arrangements will be ideal for all children). Other impacts must also be considered. A strong gender thread runs through this discussion, because the parents who take parental leave are primarily women. Thus, if there are long-term impacts of lengthy leaves on parents' employment and earnings, they will likely affect mostly women, and these effects should be taken into account as well.

Several conclusions, however, are clear. With regard to parental leave, extending the total duration of childbirth-related leave to 10 months (the OECD average), and providing universal and paid coverage as other countries do, would be prudent steps. In the area of child care, providing more support for the costs of care for children under age three, moving toward universal and publicly funded preschool provision for three- and four-year-olds, and undertaking efforts to improve the quality of care delivered to both age groups would be three important steps that would bring the United States into line with peer nations. With regard to early childhood benefits, a careful study of how such a system would fit in the U.S. policy framework, and the effects it might have on the care of young children, would be a useful next step.

This article has carefully considered the pros and cons, and the incentive effects, of various policy options. But it is important not to lose sight of the bottom line message in the comparative data. When one considers the three main types of policies that countries enact to support families in arranging care for children in early childhood-parental leave, child care, and early childhood benefits - the United States clearly provides less support to families with children under age three than all its peer nations. It is also true, as noted earlier, that the United States has a weaker system of health and social services programs for families with infants and toddlers than other countries. This lack of public support means that parents in the United States bear a larger share of the costs of raising a young child than parents bear in other countries. How to optimally provide more support for young children's care arrangements-through expanded parental leave, more support for child care, and/or the introduction of early childhood benefits-and how to expand the U.S. system of health and social services for infants and toddlers are excellent questions for further research and discussion. But enough is known now to identify useful next steps. We should not delay in making the commitment to take those next steps to provide more support to families with infants and toddlers. Our young children deserve it.

I am grateful to Sheila Kamerman for her very helpful comments on an earlier version of this article.

I am grateful to the National Institute of Child Health and Development, and the William T. Grant Foundation for funding support. 
1. U.S. Department of Health and Human Services. Indicators of welfare dependence. Washington, DC: DHHS, 1998.

2. The other 18 OECD countries not included here are Australia, Belgium, the Czech Republic, Greece, Hungary, Iceland, Ireland, Japan, the Republic of Korea, Luxembourg, Mexico, the Netherlands, New Zealand, Poland, Portugal, Spain, Switzerland, and Turkey.

3. Kamerman, S.B., and Kahn, A.J., eds. Child care, parental leave, and the under 3s: Policy innovation in Europe. New York: Auburn House, 1991.

4. Kamerman, S.B., and Kahn, A.J. Starting right: How America neglects its youngest children and what we can do about it. New York: Oxford University Press, 1995.

5. Waldfogel, J. Family leave coverage in the 1990s. Monthly Labor Review. (October 1999) 122:13-21.

6. Waldfogel, J. Family and medical leave: Evidence from the 2000 surveys. New York: Mimeo, Columbia University, 2001.

7. Commission on Family and Medical Leave. A workable balance: Report to the Congress on family and medical leave policies. Washington, DC: Women's Bureau, U.S. Department of Labor, 1996. See also Cantor, D., Waldfogel, J., Kerwin, J., et al. Balancing the needs of families and employers: Family and medical leave surveys, 2000 update. Rockville, MD: Westat, 2001.

8. Klerman, J.A., and Leibowitz, A. FMLA and the labor supply of new mothers: Evidence from the June CPS. Paper presented at the Population Association of America Annual Meeting. Chicago, IL, April 1998

9. Ross, K. Labor pains: The effects of the Family and Medical Leave Act on recent mothers' returns to work after childbirth. Paper presented at the Population Association of America Annual Meeting. Chicago, IL, April 1998.

10. Waldfogel, J. The impact of the Family and Medical Leave Act. Journal of Policy Analysis and Management (1999) 18:281-302.

11. Waldfogel, J., Han, W., and Phillips, K.R. Parental leave-taking and the FMLA. Paper presented at the Population Association of America Annual Meeting. Los Angeles, CA, March 2000.

12. Kamerman, S.B. From maternity to parental leave policies: Women's health, employment, and child and family well-being. The Journal of the American Women's Medical Association (Spring 2000) 55:96-99.

13. Kamerman, S.B. Parental leave policies: An essential ingredient in early childhood education and care policies. Social Policy Report (2000) 14:3-15.

14. Moss, P., and Deven, F.F., eds. Parental leave: Progress or pitfall? Research and policy issues in Europe. Brussels: CBGS Publications, 1999.

15. Some countries (such as Finland and Japan) also provide a lump sum cash grant to cover one-time costs associated with the new birth.

16. Ronsen, M. Assessing the impact of parental leave: Effects on fertility and employment. In Parental leave: Progress or pitfall? Research and policy issues in Europe, P. Moss and F.F. Deven, eds. Brussels: CBGS Publications, 1999, pp. 193-226.

17. Haas, L., and Hwang, P. Parental leave in Sweden. In Parental leave: Progress or pitfall? Research and policy issues in Europe, P. Moss and F.F. Deven, eds. Brussels: CBGS Publications, 1999, pp. 45-68.

18. Waldfogel, J. Family-friendly policies for families with young children. Employee Rights and Employment Policy Journal (2001) 5:101-22.

19. Ruhm, C. The economic consequences of parental leave mandates: Lessons from Europe. Quarterly Journal of Economics (1998) 113:285-318.
20. Winegarden, C.R., and Bracy, P. Demographic consequences of maternal-leave programs in industrial countries: Evidence from fixed effects models. Southern Economic Journal (1995) 61:1020-35.

21. Core, F., and Koutsogeorgopoulou, V. Parental leave: What and where? The OECD Observer (August/September 1995) 195:15-21.

22. Ruhm, C. Parental leave and child health. Journal of Health Economics (2000) 19:931-60.

23. Cunningham, A.S., Jelliffe, D.B., and Jelliffe, E.F.P. Breast-feeding and health in the 1980s: A global epidemiological review. The Journal of Pediatrics (1991) 118:659-66.

24. Lindberg, L. Women's decisions about breast-feeding and maternal employment. Journal of Marriage and the Family (1996) 58:239-51; see also Roe, B., Whittington, L., Fein, S., and Teisl, M. The conflict between breast-feeding and maternal employment. Paper presented at the Population Association of America Annual Meeting. New Orleans, LA, May 1996.

25. Han, W., Waldfogel, J., and Brooks-Gunn, J. The effects of early maternal employment on later cognitive and behavioral outcomes. The Journal of Marriage and the Family (2001) 63:336-54.

26. Kamerman, S.B. Early childhood education and care: An overview of developments in the OECD countries. International Journal of Educational Research (2000) 33:7-29.

27. Meyers, M.K. and Gornick, J. Cross-national variation in ECEC service organization and financing. In Early childhood education and care: International perspectives, S.B. Kamerman, ed. New York: Institute for Child and Family Policy, Columbia University, 2001, pp. 141-76.

28. Gomby, D., Krantzler, N., Larner, M., et al. Financing child care: Analysis and recommendations. The Future of Children (Summer/Fall 1996) 6(2):5-25.

29. Gormley, W.T. Everybody's children: Child care as a public problem. Washington, DC: The Brookings Institution, 1995. See also Helburn, S., ed. Cost, quality, and child outcomes in child care centers: Technical report. Denver, CO: Economics Department, University of Colorado, 1995.

30. Anderson, D., and Levine, P. Child care and mother's employment decisions. In Finding jobs: Work and welfare reform, D. Card and R. Blank, eds. New York: Russell Sage Foundation, 2000, pp. 420-62.

31. Kamerman, S.B. Family policy and the under-3s: Money, services, and time in a policy package. International Social Security Review (1994) 47:31-43.

32. Salmi, M., and Lammi-Taskula, J. Parental leave in Finland. In Parental leave: Progress or pitfall? Research and policy isues in Europe, $P$. Moss and F.F. Deven, eds. Brussels: CBGS Publications, 1999, pp. $85-122$.

33. Ilmakunnas, S. Female labour supply and work incentives. Helsinki: Labour Institute for Economic Research, 1997.

34. Leira, A. Cash-for-child care and daddy leave. In Parental leave: Progress or pitfall? Research and policy issues in Europe, P. Moss and F.F. Deven, eds. Brussels: CBGS Publications, 1999.

35. Personal correspondence with Harriet Harmon, Member of Parliament, U.K., 1999.

36. Bergmann, B.R. Subsidizing child care by mothers at home. New York: Foundation for Child Development Working Paper Series, 1999.

37. Besharov, D., and Samari, N. Child-care vouchers and cash payments. In Vouchers and the provision of public services, C.E. Steuerle, V.D. Ooms, G.E. Peterson, and R.D. Reischauer, eds. Washington, DC: The Brookings Institution, 2000, pp. 195-223. 